\title{
Assessment of the Effect of Organic Matter on the Retention of Lead in Perturbed Soils.
}

Rubén Albeiro Sánchez-Andica ( $\square$ ruben.sanchez@correounivalle.edu.co)

Universidad del Valle https://orcid.org/0000-0002-1591-9314

Andrés Felipe Chamorro-Rengifo

Universidad del Valle

Martha Isabel Páez Melo

Universidad del Valle https://orcid.org/0000-0003-2967-3893

\section{Research Article}

Keywords: Lead retention, Perturbed soils, Adsorption models, Kinetic models, organic matter

Posted Date: February 3rd, 2021

DOl: https://doi.org/10.21203/rs.3.rs-176564/v1

License: (1) This work is licensed under a Creative Commons Attribution 4.0 International License.

Read Full License 
Title:

\title{
Assessment of the Effect of Organic Matter on the Retention of Lead in Perturbed Soils.
}

\section{Full name of authors:}

1. Rubén Albeiro Sánchez-Andica

2. Andrés Felipe Chamorro-Rengifo

3. Martha Isabel Páez-Melo

Affiliation and address of authors

Grupo de Investigación en Contaminación Ambiental por Metales Pesados y Plaguicidas, GICAMP, Departamento de Química, Universidad del Valle, Calle 13 No 100-00, Cali-Colombia, CP 760036.

E-mail of the corresponding author:

e-mail: ruben.sanchez@correounivalle.edu.co

ORCID of the authors:

Rubén Albeiro Sánchez Andica: https://orcid.org/0000-0002-1591-9314.

Martha Isabel Páez Melo: https://orcid.org/0000-0003-2967-3893

\begin{abstract}
Four types of soils were prepared with humified matter, bentonite, kaolin and inert matter, in order to control the organic matter (OM) content in the evaluation of retention of lead (II) by adsorption in disturbed soils with the possibility of being contaminated. The results indicated that retention capacity of $\mathrm{Pb}^{+2}$ increases as organic matter increases, however, this retention is not proportional to the organic matter increment. An increase of 10 units in the concentration of the background solution results in a decrease in the retention capacity of $50 \%$. The outcomes also indicated that lead (II) adsorption is successfully explained by the Langmuir model and the adsorption kinetics fitted well to the Ho pseudo second order model. The thermodynamic values of the Gibbs free energy indicated that it was a spontaneous process and the energy of the process suggests a retention mechanism by ion exchange. A soil with high content of organic matter does not guarantee high retention of lead, even more so when the adsorption mechanism is given by ion exchange.
\end{abstract}

Keywords: Lead retention, Perturbed soils, Adsorption models, Kinetic models, organic matter.

\section{Declarations:}

Funding: No funding was received for conducting this study.

Conflicts of interest/Competing interests: The authors declare that they have no conflict of interest.

Availability of data and material: The authors confirm that the data supporting the findings of this study are available within the article 
Code availability: Not applicable

Authors' contributions: Rubén Albeiro Sánchez-Andica: Conceptualization, Methodology, Supervision, Writing-Review \& Editing Andrés Felipe Chamorro-Rengifo: Investigation, Validation, Writing-Original Draft Martha Isabel Páez-Melo: Resources, Supervision.

Acknowledgements:

The authors gratefully acknowledge to Department of Chemistry of the Universidad del Valle for allowing the use of the equipment. 


\section{Introduction}

A considerable number of products widely used in agriculture, such as fertilizers, pesticides, raw materials, growth factors, among others, are found to be contaminated with heavy metals e.g. lead, mercury, cadmium, etc. The continuous use of these products in farming activity has increased the likelihood of environmental pollution with heavy metals by retention, leaching, run-off, migration to underground waters and, finally their distribution to food chain (Wang et al., 2016; Kaurin et al., 2018), affecting the economy and human health (Sharma \& Dubey, 2005; Fahr et al., 2013; Kushwaha et al., 2018). Therefore, the accumulation and behavior of heavy metals in soils is an issue of a scientific interest.

The retention of heavy metals in soils is determined by their adsorption and desorption capacity at the surface of the particles that make up the soil. These two processes have already been studied with several metals in soils from different parts of the world (Fonseca et al., 2009; Prado et al., 2010; Pokrovsky et al., 2012; Park et al., 2018). The soils differ by the concentration of their components, especially OM, clay minerals, metallic oxides, among others (Momčilović et al., 2011; Pontoni et al., 2016; Qu et al., 2018). Moreover, some studies suggest that the adsorption process is the best method to understand the retention of heavy metals from soils (Zhang et al., 2017; Chakarborty et al., 2020).

The magnitude of the metal adsorption/desorption in soils depends on the properties such as texture, cation exchange capacity, moisture, and $\mathrm{pH}$. These properties also regulate the mobility (distribution and mass transfer) of heavy metals to the environment (Uchimiya et al., 2011; Zeng et al., 2011). However, there are two parameters that have the most influence on the adsorption process: $\mathrm{pH}$ and $\mathrm{OM}$ (measured as organic carbon). $\mathrm{pH}$ in soils determine the speciation, solubility, and bioavailability of heavy metals (Oste et al., 2002; Li et al., 2003; Tan et al., 2008), such is the case of soils contaminated with Pb, Cd, and Zn, where soil acidic conditions $(\mathrm{pH}<7)$ do not facilitate the adsorption of metals, favoring their desorption (Oste et al., 2002; Zhang et al., 2005).

On the other hand, OM has been considered the primary cause of metal retention in soils (including lead), due to the great number of functional groups of the organic compounds that may interact with metals generating retention and immobilization (Zeng et al., 2011). In soils at $\mathrm{pH}>7$, the adsorption process is affected by the concentration of the humic and fulvic acids. These acids provide negatively charged functional groups such as carboxylic, phenolic, and hydroxyl groups, which allow binding to metal ions by electrostatic interactions (Gustafsson et al., 2003; Shi et al., 2016). 
The capacity of a soil to retain heavy metals can be determined if the adsorption mechanism is established (Chakarborty et al., 2020). In an adsorption process there are three fundamental steps: first, mass transfer from the solution to the surface of the adsorbent, second, diffusion of the adsorbate to the sorption sites, and third, the adsorption itself which is obtained by adsorbate-adsorbent equilibrium (Largitte \& Pasquier, 2016). Some models consider that the limiting step is sorption, while others consider diffusion as the limiting step. The model that best fits the experimental data allows to deduce the adsorption mechanism, which could be by chemisorption or physisorption (Limousin et al., 2007).

The prediction, modeling, and thermodynamics of lead retention in different types of soils have been extensively investigated using kinetic and adsorption models (Li et al., 2003; Zhang et al., 2005; Fu et al., 2015). However, there is not enough information in the literature about the effect of different OM concentrations in the same soil for lead adsorption and mobility, mainly due to the difficulty in controlling its composition.

In this study, four types of soils were prepared (perturbed soils) with different amounts of OM, bentonite, kaolin and inert matter, in order to determine its effect on lead retention in soils.

\section{Materials and Methods}

\subsection{Preparation of perturbed soils and characterization}

All experiments were carried out with perturbed soils samples where the concentration of OM were mainly controlled. The soils were prepared in the laboratory by mixing humus (purchased in an agrochemical store), bentonite, kaolin, and inert matter (polyvinyl chloride, PVC) to obtain samples with different OM content. All raw materials were commercial grade and purchased from regular stores. Before mixing, the components were dried, finely ground, and sieved to 170 mesh (W.S Tyler, Incorporated, USA). The soils were characterized by analysis of oxidizable organic carbon, cation exchange capacity, water retention capacity, $\mathrm{pH}$, carbonates, sulfates, phosphates, and humic and fulvic acids. These parameters were analyzed by following standardized methods of the Colombian Technical Standard, NTC-5167 (ICONTEC, 2011).

\subsection{Chemicals}

Lead stock solution was prepared from lead (II) nitrate $\left(\mathrm{Pb}\left(\mathrm{NO}_{3}\right)_{2}\right)$ analytical grade salt (Sigma-Aldrich, USA). Working solutions, used in all the experiments, were prepared by dilutions of the $\mathrm{Pb}^{+2}$ stock solution plus $0,01 \mathrm{M} \mathrm{NaNO}_{3}$ as a background solution at $298 \mathrm{~K} \pm 1 \mathrm{~K}$ and adjusted at $\mathrm{pH} 7$ by adding small volumes 
of $0.01 \mathrm{M} \mathrm{HNO}_{3}$ solution (Sigma-Aldrich, USA). All the solutions were diluted with de-ionized water (type I).

\subsection{Batch sorption experiments}

Batch sorption experiments were carried out following the procedure reported by Liu (Liu \& Gonzalez, 2000). In a stoppered $50 \mathrm{~mL}$ polyethylene test tube, $0,5 \mathrm{~g} \pm 0,0001 \mathrm{~g}$ of perturbed soil and $25,00 \mathrm{~mL}$ of lead (II) working solution (from $0 \mathrm{mg} / \mathrm{L}$ up to $3000 \mathrm{mg} / \mathrm{L}$ ) were added. This mixture was mechanically stirred for 24 hours at room temperature (298 K). Afterward, the solutions were centrifuged at $3000 \mathrm{rpm}$ for 30 minutes, filtered in a black band Whatman filter paper (No 42) and collected into a volumetric flask. The non-adsorbed lead was determined in the filtrates by atomic absorption spectroscopy (Perkin Elmer AAnalyst 100).

\subsection{Sorption kinetics experiments}

The kinetic experiments were conducted by batch sorption experiments using a $500 \mathrm{mg} / \mathrm{L}$ lead (II) working solution and kept in stirring at different times (3, 5, 10, 15, 20, 30, 60, 90, 180, 270 and 360 minutes). Once the samples were centrifuged and filtered, the non-adsorbed lead in solution was determined by atomic absorption spectroscopy.

\subsection{Effect of the organic matter content}

The effect of $\mathrm{OM}$ on lead retention was studied in perturbed soils with $0 \%$ (0-OM), 1\% (1-OM), 5\% (5-OM) and $10 \%(10-\mathrm{OM})$, prepared as described above. The procedure for the sorption and kinetic experiments was described previously. All the experiments were performed by triplicate.

The simultaneous effect of two factors (OM concentration and initial lead (II) concentration) on lead adsorption capacity (response variable) was evaluated using a multilevel factorial experimental design (central composite design) and analyzed by the Response Surface Methodology (RSM). The behavior of the response variable due to the effect of the factors was studied by the second order polynomial model (Eq. 1):

$$
Y=\beta_{0}+\sum_{i=1}^{k} \beta_{i} x_{i}+\sum_{i=1}^{k} \beta_{i i} x_{i}^{2}+\sum_{i=1}^{k-1} \sum_{j=2}^{k} \beta_{i j} x_{i} x_{j}+\varepsilon
$$

Where $Y$ is the response of the model, $x_{i}, x_{j} \ldots x_{k}$ are the factors affecting the response $Y, x^{2}, x_{j}^{2}, x^{2}{ }_{k}$, are the quadratic effects $x_{i} x_{j}, x_{i} x_{k}$ and $x_{j} x_{k}$ are the interaction effects, $\beta_{0}$ is the intercept term, $\beta_{i}$ is the linear effect 
coefficient, $\beta_{i i}$ is the squared effect coefficient, $\beta_{i j}$ is the interaction effect coefficient and $\varepsilon$ is the random error (Gutiérrez \& Vara, 2004).

\subsection{Adsorption isotherms and kinetic models}

In order to calculate the equilibrium $\mathrm{Pb}^{+2}$ concentration and the adsorption kinetics in the soils, the volume was considered constant during the process, that is, the volatilization losses were negligible. The amount of $\mathrm{Pb}^{+2}$ adsorbed $(\mathrm{mg} / \mathrm{g})$ or the retention capacity $\left(q_{e}\right)$ at equilibrium time was calculated by Eq. 2 .

$$
q_{e}=\left[\frac{C_{i}-C_{e}}{M}\right] V
$$

where $C_{i}$ and $C_{e}$ are the initial and equilibrium concentrations of $\mathrm{Pb}^{+2}\left(\mathrm{mg}_{/} \mathrm{L}\right), M$ is the mass of soil $(\mathrm{g})$ and $V$ is the volume of solution (L) (Pokrovsky et al., 2012).

\subsection{Adsorption equilibrium}

The interaction between adsorbate $\left(\mathrm{Pb}^{+2}\right)$ and adsorbent (soil) in equilibrium can be described by the adsorption isotherm. This provides information on the capacity of the soil to retain $\mathrm{Pb}^{+2}$. In addition, it helps to understand the adsorption mechanism. Three models were studied for this system: Langmuir, Freundlich and Dubinin-Radushkevich (D-R), whose linearized equations (Eq. 3 - Eq.5) are shown in table 1 (Momcilovic et al., 2011; Al-Gouti \& Da'ana, 2020; Karim et al., 2020).

Table 1. Isotherm mathematical models for adsorption process

\begin{tabular}{ccc}
\hline Isotherm model & Linearized equation \\
\hline Langmuir & $\frac{C_{e}}{q_{e}}=\frac{1}{q_{\max } K_{L}}+\frac{C_{e}}{q_{\max }}$ \\
\hline Freundlich & $\log q_{e}=\log K_{F}+\frac{1}{n_{F}} \log C_{e}$ \\
\hline $\mathrm{D}-\mathrm{R}$ & $\ln q_{e}=\ln q_{D R}-K_{D R} \cdot \varepsilon^{2}$ & (Eq. 3) \\
\hline
\end{tabular}

\subsection{Kinetic theory models}

Mathematical models that describe adsorption kinetics can be classified into two categories, depending on the limiting step of the adsorption process: adsorption models and diffusional models (Qiu, 2009). In this study, two adsorption models (Largergren's first order and Ho's pseudo-second order) and two diffusional models (intraparticle diffusion and liquid film diffusion) were applied. The linearized equations of the kinetic 
models (Eq. 6 - Eq. 9) are presented in table 2 (Ho \& McKay, 1999; Qiu et al., 2009; Gupta et al., 2011; Das et al., 2014).

Table 2. Linearized equations of the adsorption kinetic models

\begin{tabular}{lcc}
\hline \multicolumn{1}{c}{ Isotherm model } & \multicolumn{1}{c}{ Linearized equation } \\
\hline Lagergren pseudo-first-order model & $\ln \left(q_{e}-q_{t}\right)=\ln q_{e}-k_{1} t$ \\
\hline Ho pseudo-second-order model & $\frac{t}{q_{t}}=\frac{1}{K_{2} q_{e}^{2}}+\left(\frac{1}{q_{e}}\right) t$ & (Eq. 6) \\
\hline Intra-particle diffusion model & $q_{t}=k_{i} t^{1 / 2}+C$ & (Eq. 8) \\
\hline Liquid film diffusion model & $\ln (1-F)=-k_{f} t$ & (Eq. 9)
\end{tabular}

\subsection{Statistical Analysis}

All the experimental data were performed in triplicate. All results are expressed as mean of the triplicates. Multilevel factorial experimental design was performed to determine the effects of the two factors (OM content and initial lead concentration) over adsorption capacity. The RSM and the ANOVA were ran using STATGRAPHICS 18 centurion software (Statgraphics Technologies, Inc., Virginia). Excel® was also used as calculation and graphical software when necessary.

\section{Results and Discussion}

\subsection{Perturbed Soils characterization}

The physical-chemical properties of the studied soils are important to help to elucidate the adsorption and retention results of $\mathrm{Pb}^{+2}$, as well as to predict the behavior of the process. The soils were designed to maintain kaolin and bentonite concentrations fixed (ca $11.5 \% \mathrm{w} / \mathrm{w}$ ), so their effect on lead retention is considered constant. The inert matter (PVC) content is variable, but, because the adsorption of $\mathrm{Pb}^{+2}$ is negligible, it is considered to have no effect on the retention of lead. The OM concentration (humified material) is variable, and it is assumed to be the only component responsible for the changes in the physicochemical properties of the soils and, hence, for the retention of the metal. Table 3 summarizes the results of the characterization of the soils. 
Table 3. Physicochemical properties of perturbed soils with different OM content

\begin{tabular}{|c|c|c|c|c|c|c|c|c|}
\hline \multirow{2}{*}{ Properties } & \multicolumn{2}{|c|}{ 10-OM } & \multicolumn{2}{|c|}{$5-\mathrm{OM}$} & \multicolumn{2}{|c|}{ 1- OM } & \multicolumn{2}{|c|}{$0-\mathrm{OM}$} \\
\hline & Value & $\% \mathrm{RSD}$ & Value & $\% \mathrm{RSD}$ & Value & $\% \mathrm{RSD}$ & Value & $\% \mathrm{RSD}$ \\
\hline Total Lead as $\mathrm{Pb}, \mathrm{mg} / \mathrm{Kg}$ (a) & $<0.41$ & & $<0.41$ & & $<0.41$ & & $<0.41$ & \\
\hline $\begin{array}{l}\text { Oxidizable organic carbon, } \\
\%(\mathrm{w} / \mathrm{w})\end{array}$ & 10.65 & 1.94 & 5.08 & 0.34 & 1.68 & 1.99 & 0.18 & \\
\hline $\begin{array}{l}\text { Water retention capacity, \% } \\
(\mathrm{v} / \mathrm{w})\end{array}$ & 79.39 & 0.0037 & 59.59 & 0.0056 & 49.68 & 0.0019 & 39.66 & 0.0042 \\
\hline $\begin{array}{l}\text { Cation-exchange capacity, } \\
\text { meq/100 } \mathrm{g}\end{array}$ & 51 & 2.71 & 38 & 3.97 & 26 & 3.17 & 12 & 2.24 \\
\hline Humic acids, \% (w/w) & 2.02 & 0.94 & 1.09 & 0.60 & 0.26 & 0.10 & 0 & - \\
\hline Fulvic acids, $\%(\mathrm{w} / \mathrm{w})$ & 5.97 & 0.62 & 2.89 & 0.74 & 0.61 & 0.98 & 0 & - \\
\hline $\mathrm{pH}, \mathrm{pH}$ units & 6.41 & - & 6.61 & - & 6.92 & - & 7.09 & - \\
\hline
\end{tabular}

(a) Concentration lower than detection limit (DL)

The variation in the $\mathrm{OM}$ concentration influence the physical-chemical properties of soils by changing the chemical composition, thus, the water retention capacity and humic and fulvic acids increase linearly with the increase in the concentration of total organic carbon, while cation exchange capacity increases quadratically. This drives to the assumption that soils with a high OM concentration can mobilize more cations on the surface of the soil particles and, not necessarily, retain them. In short, a high cation exchange capacity generates greater metal mobility (Vega et al., 2009). Since the 0-OM soil has no added OM, the value obtained from the reported oxidizable organic carbon is due to the reduction of chromium VI, based on the Walkley-Black method (ICONTEC, 2011). This outcome is corroborated by the values of humic and fulvic acids, which are directly involved in the adsorption and retention of lead. The original concentration of $\mathrm{Pb}$ in the soils was found to be less than the detection limit of the analytical method $(<0,41 \mathrm{mg} / \mathrm{L})$. Furthermore, the concentration of sulfates, carbonates and phosphates (not shown) was not detectable, which avoids losses due to interaction and precipitation with $\mathrm{Pb}^{+2}$ in the retention experiments (Nejad et al., 2018).

\subsection{Study of the retention of $\mathrm{Pb}^{+2}$ based on the adsorption isotherms}

The retention of $\mathrm{Pb}^{+2}$ in the perturbed soils was determined by adsorption isotherms $\left(C_{e}\right.$ vs $\left.q_{e}\right)$. The data corresponding to each soil were adjusted to the mathematical models of the isotherms (Langmuir, Freundlich and D - R). A detailed analysis of the parameters, obtained from the linearization of the adsorption equations 
(see table 4) determines which model is the most suitable to describe the lead adsorption process (Chotpantarat et al., 2011). The plots of the isotherms (Fig 1) show that 1-OM soil presents a slightly higher lead retention (taken as $q_{\max }$ ) than $0-\mathrm{OM}$ (soil with only bentonite and kaolin) at low concentrations of $\mathrm{Pb}^{+2}$ (10 to $400 \mathrm{mg} / \mathrm{L}$ ), while at high concentrations (400 to $3000 \mathrm{mg} / \mathrm{L}$ ) the retention becomes very similar. In soils with higher OM content (5-OM and 10-OM) a stronger effect on lead retention was observed. However, the $q_{\max } / O M$ ratio decreases as MO increases as follows, 7,948 for 10-OM, 12,2 for 5-OM and 20,89 for 1OM. This means that, although a soil with a high concentration of OM has a high capacity to retain lead (II), this increase is not proportional to the increase in OM.

The results of fitting the data to the mathematical adsorption models are shown in table 4 .

Table 4. Parameters extracted from adsorption of $\mathrm{Pb}^{+2}$ on soil with different $\mathrm{OM}$ composition using isotherm models in $\mathrm{pH} 7.0, \mathrm{I}=0.01 \mathrm{M} \mathrm{NaNO}_{3}$ at $298.15 \mathrm{~K}$

\begin{tabular}{ccccc}
\hline Isotherm & $10-\mathrm{OM}$ & $5-\mathrm{OM}$ & $1-\mathrm{OM}$ & 0 -OM \\
\hline Langmuir & & & & \\
$\mathrm{q}_{\text {máx }}(\mathrm{mg} / \mathrm{g})$ & 79.48 & 61.61 & 20.89 & 19.74 \\
$\mathrm{~K}_{\mathrm{L}}\left(\mathrm{L} / \mathrm{g}, 10^{-3}\right)$ & 13.70 & 9.65 & 3.20 & 1.02 \\
$\Delta G^{o}(\mathrm{~kJ} / \mathrm{mol})$ & -10.62 & -11.50 & -14.23 & -17.06 \\
$\mathrm{R}^{2}$ & 0.973 & 0.984 & 0.999 & 0.994 \\
\hline Freundlich & & & & \\
$\mathrm{K}_{\mathrm{F}}(\mathrm{L} / \mathrm{g})$ & 7.22 & 4.67 & 4.57 & 2.87 \\
$1 / \mathrm{n}_{\mathrm{F}}$ & 3.058 & 2.882 & 4.201 & 3.460 \\
$\mathrm{R}^{2}$ & 0.807 & 0.880 & 0.861 & 0.949 \\
\hline $\mathbf{D}^{-R}$ & & & & \\
$\mathrm{q}_{\mathrm{DR}}(\mathrm{mg} / \mathrm{g})$ & 114.27 & 87.32 & 33.68 & 33.46 \\
$\mathrm{~K}_{\mathrm{DR}}\left(\mathrm{mol} / \mathrm{J}^{2}, 10^{-2}\right)$ & 0.31 & 0.33 & 0.23 & 0.28 \\
$\mathrm{E}(\mathrm{kJ} / \mathrm{mol})$ & 12.70 & 12.30 & 14.74 & 13.36 \\
$\mathrm{R}^{2}$ & 0.821 & 0.886 & 0.908 & 0.962 \\
\hline
\end{tabular}

The corresponding graphs to the linearization of Langmuir isotherms is shown in Fig 2.

From the results obtained, it is evident that the OM concentration in a soil affects the retention or leaching of $\mathrm{Pb}^{+2}$, depending on the concentration of the metal. At low concentrations of $\mathrm{Pb}^{+2}$ (below $200 \mathrm{ppm}$ ) it is observed that the adsorption or retention capacity presents a clear difference according to the OM content, however, at high concentrations of $\mathrm{Pb}^{+2}$ (above $1000 \mathrm{ppm}$ ) this difference is a little less. In a soil with good OM content, humic and fulvic acids (main components), have a considerable number of functional groups ($\mathrm{COOH},-\mathrm{OH},-\mathrm{NH}_{2}$, etc.),) that produce a negative layer on the soil particles able to interact with the cations, 
under suitable conditions of humidity and $\mathrm{pH}$ (Wu et al., 2003). Nevertheless, there are two factors that influence the reduction in the retention capacity. First, in a soil with a high OM content, the aggregation of particles reduces the active surface and, hence, the negative layer available for metal adsorption become less (Khan et al., 2018). And second, in soils with high OM content (above $2.1 \%$ and $0.88 \%$ of humic acids) the solubility of organic carbon facilitates the interaction between humic and fulvic acids with $\mathrm{Pb}^{+2}$ in solution, avoiding retention in the solid fraction of the soil. In the organic carbon solubilization, two chemical equilibriums can occur, represented by Eq. 10 and Eq. 11.

$$
\begin{aligned}
& P b_{(a q)}^{2+}+x(S)_{(s)}^{-} \rightleftharpoons P b(S)_{x}^{(x-2)^{-}}{ }_{(s)} \rightleftharpoons \quad K_{P b(S)_{x}^{(x-2)^{-}}}=\frac{\gamma_{P b(S)_{x}^{(x-2)^{-}} \cdot\left[P b(S)_{x}^{(x-2)^{-}}\right]}}{\gamma_{P b^{2+}} \cdot\left[P b^{2+}\right] \cdot \gamma_{(S)^{-}} \cdot\left[(S)^{-}\right]^{x}} \\
& P b_{(a q)}^{2+}+x(O C)_{(a q)}^{-} \rightleftharpoons P b(C O)_{x}^{(x-2)^{-}}(a q) \quad K_{P b(C O)_{x}^{(x-2)^{-}}}=\frac{\gamma_{P b(C O)_{x}^{(x-2)^{-}} \cdot\left[\mathrm{Pb}(\mathrm{CO})_{x}^{(x-2)^{-}}\right]}}{\gamma_{P b^{2+}} \cdot\left[P b^{2+}\right] \cdot \gamma_{(\mathrm{CO})^{-}} \cdot\left[(\mathrm{CO})^{-}\right]^{x}}
\end{aligned}
$$

Where $K_{P b(S)_{x}^{(x-2)^{-}}}$and $K_{P b(C O)_{x}^{(x-2)^{-}}}$are the thermodynamic equilibrium constants,$\gamma_{y}$ is the activity coefficient of the specie $\mathrm{y}$ and, $[Y]$ is the concentration of the specie $\mathrm{Y}(\mathrm{Y}=$ $\mathrm{Pb}^{2+}$ or $(S)^{-}$or $\mathrm{Pb}(S)_{x}^{(x-2)^{-}}$or $(C O)^{-}$or $\left.\mathrm{Pb}(\mathrm{CO})_{x}^{(x-2)^{-}}\right)$, being $(S)^{-}$the interaction site in the soil and, $(O C)^{-}$the soluble organic carbon. If the soluble metal-carbon equilibrium constant is higher than the metalinteraction site equilibrium constant $\left(K_{P b(C O)_{x}^{(x-2)^{-}}} \gg K_{P b(S)_{x}^{(x-2)^{-}}}\right)$, there is a high probability that the metal interacts with the soluble carbon and subsequently leaches with no interaction with the adsorption or retention sites in the soil. Organic carbon leaching is evident in soils with high OM content by the dark color of the solution, as were observed in our results. On the contrary, in soils with lower OM content (1\%), there was a considerable retention of the metal in the soil. A soil having $1 \% \mathrm{OM}$, there is little probability of finding organic carbon in solution and therefore, $\mathrm{Pb}^{+2}$ ions will not react with organic compounds in solution, but they will do with the adsorption sites in the soil, increasing the probability of being retained (Cao et al., 1999).

From Fig 2 it is easy to deduce that, qualitatively, all experimental data is fitted properly to the Langmuir isotherm, which is corroborated by the highest values of the regression coefficient (0.973 to 0.999) for all perturbed soils. This model assumes the formation of a monolayer on the surface of soil particles, which $q_{\text {máx }}$ is the concentration necessary to saturate the soil particles i.e. maximum adsorption capacity (Limousin et al., 2007). The adsorption parameters (table 4) corroborate the adsorption in monolayers, that is, the data fits very well to the Langmuir model. There are several parameters that confirm that the Langmuir isotherm fits well: Free energy, $\Delta G^{0},\left(\Delta G^{o}=-R T \ln K_{L}\right)$, gives negative values (table 4) which it can be attributed that a 
spontaneous and thermodynamically favorable process (Mishra et al., 2012). The adsorption intensity, $R_{L}$, $\left(R_{L}=\frac{1}{1+K_{L} C_{0}}\right)$, also confirms a favorable Langmuir adsorption, since the $R_{L}$ values are less than 0.1 ( 0.02 to 0.70) (Nanta et al., 2018). $1 / n_{F}$ values, obtained from the slope of linearized Freundlich equation, greater than 1, indicates that the adsorption in multilayers is unfavorable (Al-Gouthi \& Da'ana, 2020). In this case, the $1 / n_{F}$ values were above $1(2,88$ and 4,20$)$, which confirms that monolayer adsorption (described by the Langmuir model) is favorable. The $q_{\text {máx }}$ values, obtained from the slope of linearized Langmuir model, increase as the OM increases $(19,74$ to $79,48 \mathrm{mg} / \mathrm{g})$. The adsorption strength can be inferred from the $K_{L}$ coefficient and calculated from the intercept of the linearized Freundlich equation (Karim et al., 2020). The outcomes show that the $K_{L}$ value of the 1-OM soil has an appreciable difference with respect to the 0-OM soil caused by the increase in OM, however, in soils with 5-OM and 10-OM this difference is not as high as expected.

Lead retention in the 10-OM soil at two different concentrations $(0.01 \mathrm{M}$ and $0.1 \mathrm{M})$ of $\mathrm{NaNO}_{3}$ (background solution) was carried out. The outcomes show that the increasing 10-fold of background solution (from 0.01 $\mathrm{M}$ to $0.1 \mathrm{M}$ ) leads to a lower $\mathrm{Pb}^{+2}$ retention of ca $50 \%$ (Fig 3). This fact indicates that lead retention in soils is strongly affected by ionic strength.

The D-R adsorption model has been used to describe the adsorption mechanism based on the concept of adsorption free energy, where a homogeneous surface or constant sorption potential is not assumed (Lasheen et al., 2012), and to differentiate between physical, chemical, or ion exchange adsorption of metal ions (AlGouthi \& Da'ana, 2020; Wang et al., 2016). The monolayer adsorption capacity $\left(q_{D R}\right)$ obtained by D-R isotherm increases from $33.46 \mathrm{mg} / \mathrm{g}$ for $0-\mathrm{OM}$ to $114.27 \mathrm{mg} / \mathrm{g}$ for $10-\mathrm{OM}$ (table 4 ), this behavior is in accordance with the adsorption capacity calculated by Langmuir isotherm. The free adsorption energy, $E$, ( $E=\frac{1}{\sqrt{2 \mathrm{~K}_{\mathrm{DR}}}}$ ) is the energy necessary to adsorb $1 \mathrm{~mol}$ of $\mathrm{Pb}^{+2}$ from the bulk solution onto the soils particles (Sen \& Bhattacharyya, 2011). According to literature, it is considered that the process corresponds to a physical adsorption when $\mathrm{E}$ is between $1 \mathrm{~kJ} / \mathrm{mol}$ and $8 \mathrm{~kJ} / \mathrm{mol}$, ion exchange with $\mathrm{E}$ is between $8 \mathrm{~kJ} / \mathrm{mol}$ and $16 \mathrm{~kJ} / \mathrm{mol}$ and chemical adsorption when $\mathrm{E}$ is greater than $16 \mathrm{kj} / \mathrm{mol}$ (Sari et al., 2007; Wang et al., 2016). In this investigation, very similar E values were obtained for all soils (table 4), which ranged between 12,30 - 14,74 $\mathrm{kJ} / \mathrm{mol}$, indicating that the ion exchange is the mechanism that explains the adsorption process in the perturbed soils of this experiment. These results are congruent with those obtained by other researchers who have determined that the cation exchange is the mechanism used to explain the metal adsorption in a soil with OM (Gustfasson et al., 2003). 
The simultaneous effect of the OM content and initial lead concentration on adsorption capacity by a response surface plot was determined, as shown in Fig 4. In the plot, it can be seen that the two studied factors in relation to the response variable present curvatures, that is, quadratic effects. A quadratic effect suggests that the simultaneous response to the two factors is not linear (Gutiérrez \& Vara, 2004). In this sense, it corroborates the fact that for high OM concentrations the adsorption is not as high as expected.

The results of the analysis of variance of the factors showed statistical significance $(\mathrm{P}<0.05)$. The quadratic model fitting of the SRM was evaluated by the determination coefficient $\left(R^{2}\right)$. The closer $R^{2}$ is to 1 , the stronger the model, and better the model predicts the response variable (Amini et al., 2008). The value of $R^{2}$ obtained was 0,9470 with a standard deviation of 5,2, indicating that there is statistical evidence that only $5.30 \%$ of the variables are not explained by the mathematical expression (Eq. 12).

$$
Y=-4,50+0.0370 x_{1}+3.30 x_{2}-1.0 * 10^{-5} x_{1}^{2}+0,02016 x_{1} x_{2}-0,2380 x_{2}^{2}
$$

Where $Y$ corresponds to the lead adsorption capacity $\left(q_{e}\right), x_{1}$ is the initial lead concentration and $x_{2}$ is the OM concentration. The comparison between the experimental and the model data was made by means of a regression analysis (Fig 5). Note that the quadratic effect of the $\mathrm{OM}$ is higher $(-0.2380)$ than that of $\mathrm{Pb}^{+2}$ initial concentration (-0.00001) which signifies the strong effect of OM on the adsorption of the metal in the soils.

The regression $\left(R^{2}\right)$ and correlation $(r)$ coefficients obtained were 0,9469 and 0,9731 respectively, meaning that the data fit appropriately to a linear model and show good correlation between the experimental and the modeled data. The plot shows that in the middle zone (30 to $60 \mathrm{mg} / \mathrm{g}$ ) there is a smaller deviation, which suggests a better prediction of $q_{e}$.

\subsection{Adsorption kinetics}

The rate at which the analyte reaches equilibrium helps to determine the ability of soils to retain or leach metals in solution. Retention or leaching depends mainly on the physical characteristics of the material and the mechanism of interaction between soil and cations (Sen \& Bhattacharyya, 2011). Thus, a soil that takes shorter time to reach the equilibrium can retain the metal more easily, while in those systems that take longer, leaching can occur. This rate transfer of $\mathrm{Pb}^{+2}$ from the aqueous to the solid phase can occur by several processes such as chemical interaction, diffusion and mass transfer that could be determined by the adsorption kinetics (Liu \& Liu, 2008). Fig 6 shows the behavior of lead adsorption in equilibrium $\left(q_{e}\right)$ as a function of 
time, $t$, (from 3 to 360 minutes) of the soils with different OM concentration. In the four studied soils, the amount of adsorbed lead increases with time until reaching the equilibrium state. The time needed to get the equilibrium was 10 minutes for the 0-OM soil, 15 minutes for 1-OM, 20 minutes for 5-OM and 60 minutes for the 10-OM soil. Although the amount of OM in the 1-OM soil is very low, it is enough to show the difference in time at the equilibrium point with $0-\mathrm{OM}$ soil; however, the adsorption capacity is very similar at the end of the plots. In 1-OM and 5-OM soils there is not much difference in time that it takes to reach equilibrium (5 minutes); nevertheless, the difference in the $q_{e}$ value is greater. These observations agree with the $k_{2}$ value (rate constant) of the pseudo-second order model. Despite the fact that the soil with 10-OM has twice the OM content, the adsorption capacity at equilibrium is not that much. The fast lead adsorption on the different soils at the beginning may be due to the availability of the binding sites in the OM, which allows a quick interaction with lead until reaching equilibrium (Gupta et al., 2009). This fact leads to deduce that the interaction between $\mathrm{Pb}^{+2}$ and binding sites is due to chemical interactions rather than physical adsorption (Tan et al., 2008). The aggregation of the particles in the soil with higher OM content generates electrostatic and steric repulsions between the $\mathrm{Pb}^{+2}$ ions in the adsorption process (Litniewski \& Ciach, 2019) and could be the reason why this type of soil takes longer to reach equilibrium. This fact is evidenced when the ionic strength is increased using background solutions from $0.01 \mathrm{M}$ to $0.1 \mathrm{M}$, in which the repulsion and competition between the $\mathrm{Pb}^{+2}$ and $\mathrm{Na}^{+}$cations for the adsorption sites causes a decrease in the capacity of retention of ca $50 \%$.

Four kinetics models were applied to the results in order to help to derive the possible mechanism of the adsorption process (Sen \& Bhattacharyya, 2011). Table 5 shows the kinetic parameters and regression coefficients $\left(R^{2}\right)$ of the $\mathrm{Pb}^{+2}$ adsorption obtained by the four models for the tested soils.

Table 5. Kinetic parameters for the adsorption of $\mathrm{Pb}^{+2}$ ions into materials with different $\mathrm{OM}$ composition at at $298 \pm 1 \mathrm{~K}, \mathrm{pH}=7, \mathrm{I}=0.01 \mathrm{M} \mathrm{NaNO}_{3}, \mathrm{C}_{\mathrm{Pb}}{ }^{+2}{ }_{\text {(initial) }}=500 \mathrm{mg} / \mathrm{L}$

\begin{tabular}{cccccc}
\hline \multirow{2}{*}{ Models } & \multirow{2}{*}{ Parameters } & 10-OM & $5-\mathrm{OM}$ & $1-\mathrm{OM}$ & $0-\mathrm{OM}$ \\
\cline { 3 - 5 } pseudo first & $\mathrm{k}_{2}(1 / \mathrm{min})$ & 0.0344 & 0.0067 & 0.0191 & 0.0210 \\
order & $\mathrm{R}^{2}$ & 0.862 & 0.889 & 0,823 & 0,850 \\
& $\mathrm{q}_{\mathrm{e}}(\mathrm{mg} / \mathrm{g})$ & 27.62 & 20.89 & 5.39 & 4.91 \\
pseudo & $\mathrm{k}_{2}(\mathrm{~g} /(\mathrm{mg} * \mathrm{~min}))$ & $1.1 \times 10^{-3}$ & $6.0 \times 10^{-3}$ & 0.0568 & 0.0595 \\
second order & $\mathrm{R}^{2}$ & 0.989 & 0.999 & 0.999 & 0.999 \\
& & 2.248 & 0.887 & 0.155 & 0.222 \\
Intra-particle & $\mathrm{k}\left(\mathrm{mg} /\left(\mathrm{g}_{*} \min ^{1 / 2}\right)\right)$ & 0.926 & 0.807 & 0.729 & 0.810 \\
diffusion & $\mathrm{R}^{2}$ & 0.0278 & $5.5 \times 10^{-4}$ & 0.0119 & 0.0105 \\
Liquid film & $\mathrm{a}$ & 0.917 & 0.956 & 0.920 & 0.936 \\
diffusion & $\mathrm{R}^{2}$ & & & &
\end{tabular}


Taking the regression coefficient as an adjustment parameter to a linear model, it is observed that the highest $R^{2}$ values are those of the pseudo-second order model, which are 0.999 for 0-OM, 0.999 for 1-OM, 0.999 for 5-OM and 0.989 for 10-OM. Table 2 shows that all the models display regression coefficients above $70 \%$, therefore, all models present a considerable degree of fitting to the kinetics of lead-soil interaction. Soils are composed of different materials, generating a high degree of heterogeneity, where each of the components can exhibit different sort of interaction with the cation, either attraction or repulsion (Limousin et al., 2007), which explains why all the models present some adjustment. However, the model with the highest regression coefficient is the Ho's pseudosecond-order model. Furthermore, it is the only one that shows a notable variation of the rate constant $\left(k_{2}\right)$, in the following sequence: OM-10; 6x10-4<OM-5; 5.9x10-3<OM-1; $0.0625 \mathrm{~g} /\left(\mathrm{mg}^{*} \mathrm{~min}\right)$

From the above, it can be concluded that the equilibrium constant has a tendency to increase with the decrease in OM, in other words, the rate of interaction is higher at low OM concentrations. Ho and Mckey (1999) assume that the pseudo-second order model "is based on the assumption that the rate-limiting step may be chemical surprise or chemisorption involving valency forces through sharing or exchange of electrons between sorbent and sorbate", which is consistent with the $E$ values found from the Langmuir model, from which it is concluded that lead interacts with carboxylic and phenolics groups from OM by ion exchange (Mohapatra et al., 2009; Özca et al., 2009; Qiu et al., 2009). The importance of these groups in the adsorption of heavy metals, including lead, was observed by shi et al. (2016). Note that the value of $R^{2}$ for $10-\mathrm{OM}$ is not as high as in the other soils, meaning a higher deviation of the adsorption process. This deviation may occur for the decreasing of the adsorption of lead at high OM content. A conclusion that can be drawn from this work is that a high OM concentration does not guarantee a proportional retention of lead that, from an environmental point of view, could cause leaching and runoff of the metal.

On the other hand, the thin film diffusion model assumes the flow of cations on the adsorbent surface, this being the limiting step in adsorption kinetics (Momčilović et al.., 2011). The diffusion coefficient values found (table 5) are high in contrast to values found in the literature of $10^{-10}$ to $10^{-3}$ (Sen \& Bhattacharyya, 2011), which suggests that there is a high flux of $\mathrm{Pb}^{2+}$ ions on the surface of the soil particles. In this way, it is possible to discard that the limiting step in the adsorption kinetics is the transference of the ion to the surface of the adsorbent. 


\section{Conclusions}

The results showed that lead retention increased with increasing organic matter concentration. This difference in lead retention can be attributed to the effect of organic matter. The increase in lead retention does not occur in the same proportion as the increase in organic matter content. The application of the mathematical models of adsorption allows to conclude that the Langmuir model is the one that best fit the experimental data, which suggests an adsorption on the surface of the soil particles in monolayer.

The findings showed that the process was thermodynamically spontaneous and exothermic. The application of the response surface model allowed to determine the quadratic effects of the two evaluated factors, that led to corroborate that lead adsorption in soils is not proportional with OM concentration. The adsorption of $\mathrm{Pb}^{+2}$ in the perturbed soils followed the pseudo-second order kinetic model. This model allowed to deduce that the adsorption mechanism occurs by ion exchange, which is confirmed by the decrease in the lead retention when the background solution increases the concentration by ten-fold. Finally, it can be concluded from the results that a soil with high organic matter content does not retain $\mathrm{Pb}^{+2}$ completely and allows it to filter into the soil polluting groundwater. This fact must be taken into account when designing soil remediation methods by adding substances that immobilize the metal by means of stronger energy adsorption.

\section{References}

Al-Ghouti, M. A., \& Da'ana, D. A. (2020). Guidelines for the use and interpretation of adsorption isotherm models: A review. Journal of Hazardous Materials, 122383. https://doi.org/10.1016/j.jhazmat.2020.122383.

Amini, M., Younesi, H., Bahramifar, N., Lorestani, A. A. Z., Ghorbani, F., Daneshi, A., \& Sharifzadeh, M. (2008). Application of response surface methodology for optimization of lead biosorption in an aqueous solution by Aspergillus niger. Journal of hazardous Materials, 154(1-3), 694-702. https://doi.org/10.1016/j.jhazmat.2007.10.114.

Arco-Lázaro, E., Pardo, T., Clemente, R., Bernal, M.P., (2018). Arsenic adsorption and plant availability in an agricultural soil irrigated with As-rich water: Effects of Fe-rich amendments and organic and inorganic fertilisers. Journal of Environmental Management. 262-272. https://doi.org/10.1016/j.jenvman.2017.12.042.

Cai, M., McBride, M.B., Li, K., Li, Z., (2017). Bioaccessibility of As and Pb in orchard and urban soils amended with phosphate, $\mathrm{Fe}$ oxide and organic matter. Chemosphere, 173, 153-159. https://doi.org/10.1016/j.chemosphere.2017.01.049.

Cao, J., Tao, S., \& Li, B. G. (1999). Leaching kinetics of water soluble organic carbon (WSOC) from upland soil. Chemosphere, 39(11), 1771-1780. https://doi.org/10.1016/S0045-6535(99)00071-5

Chakraborty, R., Asthana, A., Singh, A. K., Jain, B., \& Susan, A. B. H. (2020). Adsorption of heavy metal ions by various low-cost adsorbents: a review. International Journal of Environmental Analytical Chemistry, 1-38. https://doi.org/10.1080/03067319.2020.1722811.

Chang, P., Wang, X., Yu, S., Wu, W., (2007). Sorption of Ni(II) on Na-rectorite from aqueous solution: Effect of pH, ionic strength and temperature. Colloids Surfaces A Physicochem. Eng. Asp. 302, 75-81. 
https://doi.org/10.1016/j.colsurfa.2007.01.040.

Chotpantarat, S., Ong, S. K., Sutthirat, C., \& Osathaphan, K. (2011). Effect of pH on transport of Pb2+, $\mathrm{Mn} 2+, \mathrm{Zn} 2+$ and $\mathrm{Ni2}+$ through lateritic soil: column experiments and transport modeling. Journal of Environmental Sciences, 23(4), 640-648. https://doi.org/10.1016/S1001-0742(10)60417-2

Das, B., Mondal, N. K., Bhaumik, R., \& Roy, P. (2014). Insight into adsorption equilibrium, kinetics and thermodynamics of lead onto alluvial soil. International Journal of Environmental Science and Technology, 11(4), https://doi.org/1101-1114. 10.1007/s13762-013-0279-z.

Fahr, M., Laplaze, L., Bendaou, N., Hocher, V., Mzibri, M. El, Bogusz, D., Smouni, A., (2013). Effect of lead on root growth. Frontiers in Plant Science, 4, 1-7. https://doi.org/10.3389/fpls.2013.00175.

Fonseca, B., Maio, H., Quintelas, C., Teixeira, A., Tavares, T., (2009). Retention of $\mathrm{Cr}(\mathrm{VI})$ and $\mathrm{Pb}(\mathrm{II})$ on a loamy sand soil. Kinetics, equilibria and breakthrough, Chemical Engineering Journal, 152, 212-219. https://doi.org/10.1016/j.cej.2009.04.045.

Fu, H., Chai, T., Huang, G., Gao, P., Liu, Z., (2015). Effects of rhamnolipid on the adsorption of Pb2+ onto compost humic acid, Desalination and Water Treatment, 54, 3177-3183. https://doi.org/10.1080/19443994.2014.943059.

Gupta, S., Kumar, D., \& Gaur, J. P. (2009). Kinetic and isotherm modeling of lead (II) sorption onto some

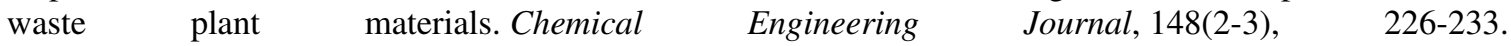
https://doi.org/10.1016/j.cej.2008.08.019.

Gupta, V.K., Agarwal, S., Saleh, T.A., (2011). Synthesis and characterization of alumina-coated carbon nanotubes and their application for lead removal. Journal of Hazardous Material. 185, 17-23. https://doi.org/10.1016/j.jhazmat.2010.08.053.

Gustafsson, J.P., Pechová, P., Berggren, D., (2003). Modeling Metal Binding to Soils: The Role of Natural Organic Matter. Environmetal Science and0 Technology, 37, 2767-2774. https://doi.org/10.1021/es026249t.

Gutiérrez Pulido, H., Vara Salazar, R. d. 1. (2012). Análisis y diseño de experimentos: (3a. ed.). México D.F.: McGrawHill.

Ho, Y. S., \& McKay, G. (1999). Pseudo-second order model for sorption processes. Process biochemistry, 34(5), 451-465. https://doi.org/10.1016/S0032-9592(98)00112-5

Karim, K. H. (2020). Copper adsorption Behavior in some Calcareous Soils using Langmuir, Freundlich, Temkin, and Dubinin-Radushkevich Models. Journal of Soil Sciences and Agricultural Engineering, 11(1), 27-34. https://doi.org/10.21608/jssae.2020.79168.

Kaurin, A., Cernilogar, Z., Lestan, D., (2018). Revitalisation of metal-contaminated, EDTA-washed soil by addition of unpolluted soil, compost and biochar: Effects on soil enzyme activity, microbial community $\begin{array}{llll}\text { composition } \text { and } & \text { Chemosphere } & \text { 193, }\end{array}$ https://doi.org/10.1016/j.chemosphere.2017.11.082.

Khan, S., Ding, X., Khan, A., Alam, M., (2018). The effects of biochar and rice husk on adsorption and desorption of cadmium on to soils with different water conditions (upland and saturated). Chemosphere 193, 1120-1126. https://doi.org/10.1016/j.chemosphere.2017.11.110.

Kushwaha, A., Hans, N., Kumar, S., Rani, R., (2018). A critical review on speciation, mobilization and toxicity of lead in soil-microbe-plant system and bioremediation strategies. Ecotoxicology and Environmental Safety. 147, 1035-1045. https://doi.org/10.1016/j.ecoenv.2017.09.049.

Largitte, L., \& Pasquier, R. (2016). A review of the kinetics adsorption models and their application to the adsorption of lead by an activated carbon. Chemical Engineering Research and Design, 109, 495-504. http://dx.doi.org/10.1016/j.cherd.2016.02.006 
Lasheen, M. R., Ammar, N. S., \& Ibrahim, H. S. (2012). Adsorption/desorption of Cd (II), Cu (II) and Pb+2 using chemically modified orange peel: Equilibrium and kinetic studies. Solid State Sciences, 14(2), 202210. https://doi.org/10.1016/j.solidstatesciences.2011.11.029.

Li, K., Liu, W., Xu, D., Lee, S., (2003). Influence of organic matter and pH on bentazone sorption in soils. Journal of Agricultural and Food Chemistry. 51, 5362-5366. https://doi.org/10.1021/jf0343332.

Limousin, G., Gaudet, J.P., Charlet, L., Szenknect, S., Barthès, V., Krimissa, M., (2007). Sorption isotherms: A review on physical bases, modeling and measurement. Applied Geochemistry 22, 249-275. https://doi.org/10.1016/j.apgeochem.2006.09.010.

Litniewski, M., \& Ciach, A. (2019). Effect of aggregation on adsorption phenomena. The Journal of chemical physics, 150(23), 234702. https://doi.org/10.1063/1.5102157.

Liu, A., \& Gonzalez, R. D., (2000), Modeling adsorption of copper (II), cadmium (II) and lead (II) on purified humic acid. Langmuir, 16(8), 3902-3909. https://doi.org/10.1021/la990607x

Liu, Y., Liu, Y.J., (2008). Biosorption isotherms, kinetics and thermodynamics. Separation and Purification Technology. 61, 229-242. https://doi.org/10.1016/j.seppur.2007.10.002.

Malusis, M.A., Maneval, J.E., Barben, E.J., Shackelford, C.D., Daniels, E.R., (2010). Influence of adsorption on phenol transport through soil-bentonite vertical barriers amended with activated carbon. Journal of Contaminant Hydrology. 116, 58-72. https://doi.org/10.1016/j.jconhyd.2010.06.001.

Mishra, S., Maity, S., Bhalke, S., Pandit, G., Puranik, V., \& Kushwaha, H. (2012). Thermodynamic and kinetic investigations of uranium adsorption on soil. Journal of Radioanalytical and Nuclear Chemistry, 294(1), 97-102. https://doi.org/10.1007/s10967-011-1506-Z.

Mohapatra, M., Khatun, S., Anand, S., (2009). Pb(II) adsorption on Tata chromite mine overburden. Desalination 247, 530-539. https://doi.org/10.1016/j.desal.2008.12.038.

Momčilović, M., Purenović, M., Bojić, A., Zarubica, A., Randelovid, M., (2011). Removal of lead(II) ions from aqueous solutions by adsorption onto pine cone activated carbon. Desalination 276, 53-59. https://doi.org/10.1016/j.desal.2011.03.013.

Nanta, P., Kasemwong, K., Skolpap, W., (2018). Isotherm and kinetic modeling on superparamagnetic nanoparticles adsorption of polysaccharide. Journal of Environmental Chemical Engineering. 6, 794-802. https://doi.org/10.1016/j.jece.2017.12.063.

Nejad, Z. D., Jung, M. C., \& Kim, K. H. (2018). Remediation of soils contaminated with heavy metals with an emphasis on immobilization technology. Environmental geochemistry and health, 40(3), 927-953. https://doi.org/10.1007/s10653-017-9964-z.

Instituto Colombiano de Normas Técnicas, ICONTEC. (2011). Agricultural Industry Products. Organic Products Used As Fertilizers And Soil Amendments. (NTC 5167). https://tienda.icontec.org/

Oste, L.A., Temminghoff, E.J.M., Van Riemsdijk, W.H., (2002). Solid-solution partitioning of organic matter in soils as influenced by an increase in $\mathrm{pH}$ or Ca concentration. Environmental Science and Technology. 36, 208-214. https://doi.org/10.1021/es0100571.

Özcan, A.S., Gök, Ö., Özcan, A., (2009). Adsorption of lead(II) ions onto 8-hydroxy quinoline-immobilized bentonite. Journal of Hazardous Materials. 161, 499-509. https://doi.org/10.1016/j.jhazmat.2008.04.002.

Park, J.H., Wang, J.J., Xiao, R., Pensky, S.M., Kongchum, M., DeLaune, R.D., Seo, D.C., (2018). Mercury adsorption in the Mississippi River deltaic plain freshwater marsh soil of Louisiana Gulf coastal wetlands. Chemosphere 195, 455-462. https://doi.org/10.1016/j.chemosphere.2017.12.104.

Pokrovsky, O.S., Probst, A., Leviel, E., Liao, B., (2012). Interactions between cadmium and lead with acidic soils: Experimental evidence of similar adsorption patterns for a wide range of metal concentrations and the 
implications of metal migration. Journal of Hazardous Materials. 199-200, 358-366. https://doi.org/10.1016/j.jhazmat.2011.11.027.

Pontoni, L., van Hullebusch, E.D., Fabbricino, M., Esposito, G., Pirozzi, F., (2016). Assessment of trace heavy metals dynamics during the interaction of aqueous solutions with the artificial OECD soil: Evaluation of the effect of soil organic matter content and colloidal mobilization. Chemosphere 163, 382-391. https://doi.org/10.1016/j.chemosphere.2016.08.005.

Prado, A.G.S., Moura, A.O., Holanda, M.S., Carvalho, T.O., Andrade, R.D.A., Pescara, I.C., de Oliveira, A.H.A., Okino, E.Y.A., Pastore, T.C.M., Silva, D.J., Zara, L.F., (2010). Thermodynamic aspects of the Pb adsorption using Brazilian sawdust samples: Removal of metal ions from battery industry wastewater. Chemical Engineering Journal. 160, 549-555. https://doi.org/10.1016/j.cej.2010.03.066.

Qiu, H., Lv, L., Pan, B. C., Zhang, Q. J., Zhang, W. M., \& Zhang, Q. X. (2009). Critical review in adsorption kinetic models. Journal of Zhejiang University-Science A, 10(5), 716-724. https://doi.org/10.1631/jzus.A0820524.

Qu, C., Du, H., Ma, M., Chen, W., Cai, P., Huang, Q., (2018). Pb sorption on montmorillonite-bacteria composites: A combination study by XAFS, ITC and SCM. Chemosphere 200, 427-436. https://doi.org/10.1016/j.chemosphere.2018.02.136.

Sari, A., Tuzen, M., Citak, D., Soylak, M., (2007). Equilibrium, kinetic and thermodynamic studies of adsorption of $\mathrm{Pb}(\mathrm{II})$ from aqueous solution onto Turkish kaolinite clay. Journal of Hazardous Materiasl. 149, 283-291. https://doi.org/10.1016/j.jhazmat.2007.03.078.

Sen G., S., Bhattacharyya, K.G., (2011). Kinetics of adsorption of metal ions on inorganic materials: A review. Advances in Colloid Interface Science. 162, 39-58. https://doi.org/10.1016/j.cis.2010.12.004.

Sharma, P., Dubey, R.S., (2005). Lead toxicity in plants. Brazilian Journal of Plant Physiology. 17, 35-52. https://doi.org/10.1590/S1677-04202005000100004.

Shi, Z., Wang, P., Peng, L., Lin, Z., Dang, Z., (2016). Kinetics of Heavy Metal Dissociation from Natural Organic Matter: Roles of the Carboxylic and Phenolic Sites. Environmental Science and Technology. 50, 10476-10484. https://doi.org/10.1021/acs.est.6b01809.

Tan, X., Liu, Y., Gu, Y., Zeng, G., Wang, X., Hu, X., ... \& Yang, Z. (2015). Immobilization of Cd (II) in acid soil amended with different biochars with a long term of incubation. Environmental Science and Pollution Research, 22(16), 12597-12604. https://doi.org/10.1007/s11356-015-4523-6.

Tan, X.L., Chang, P.P., Fan, Q.H., Zhou, X., Yu, S.M., Wu, W.S., Wang, X.K., (2008). Sorption of Pb(II) on Na-rectorite: Effects of $\mathrm{pH}$, ionic strength, temperature, soil humic acid and fulvic acid. Colloids and Surfaces A: Physicochemical and Engineering Aspects. 328, 8-14. https://doi.org/10.1016/j.colsurfa.2008.06.022.

Uchimiya, M., Chang, S., Klasson, K.T., (2011). Screening biochars for heavy metal retention in soil: Role of oxygen functional groups. Journal of Hazardous Materials. 190, 432-441. https://doi.org/10.1016/j.jhazmat.2011.03.063.

Unuabonah, E. I., Adebowale, K. O., \& Olu-Owolabi, B. I. (2007). Kinetic and thermodynamic studies of the adsorption of lead (II) ions onto phosphate-modified kaolinite clay. Journal of Hazardous Materials, 144(1-2), 386-395. https://doi.org/10.1016/j.jhazmat.2006.10.046.

Vega, F. A., Covelo, E. F., \& Andrade, M. L. (2009). The role of cation exchange in the sorption of cadmium, copper and lead by soils saturated with magnesium. Journal of hazardous materials, 171(1-3), 262-267. https://doi.org/10.1016/j.jhazmat.2009.05.137

Wang, Y., Chen, Y., Xie, H., Zhang, C., Zhan, L., (2016). Lead adsorption and transport in loess-amended soil-bentonite cut-off wall. Engineering Geology. 215, 69-80. https://doi.org/10.1016/j.enggeo.2016.11.002.

Wu, Z., Gu, Z., Wang, X., Evans, L., \& Guo, H. (2003). Effects of organic acids on adsorption of lead onto 
montmorillonite, goethite and humic acid. Environmental Pollution, 121(3), 469-475. https://doi.org/10.1016/S0269-7491(02)00272-5.Khan, M.A.,

Zeng, F., Ali, S., Zhang, H., Ouyang, Y., Qiu, B., Wu, F., Zhang, G., (2011). The influence of pH and organic matter content in paddy soil on heavy metal availability and their uptake by rice plants. Environmental Pollution. 159, 84-91. https://doi.org/10.1016/j.envpol.2010.09.019.

Zhang, C., Su, J., Zhu, H., Xiong, J., Liu, X., Li, D., ... \& Li, Y. (2017). The removal of heavy metal ions from aqueous solutions by amine functionalized cellulose pretreated with microwave-H 2 O 2. RSC advances, 7(54), 34182-34191. https://doi.org/10.1039/c7ra03056h.

Zhang, M., Li, W., Yang, Y., Chen, B., Song, F., (2005). Effects of readily dispersible colloid on adsorption and transport of $\mathrm{Zn}, \mathrm{Cu}$, and $\mathrm{Pb}$ in soils. Environmental. International. 31, 840-844. https://doi.org/10.1016/j.envint.2005.05.037. 
Figures

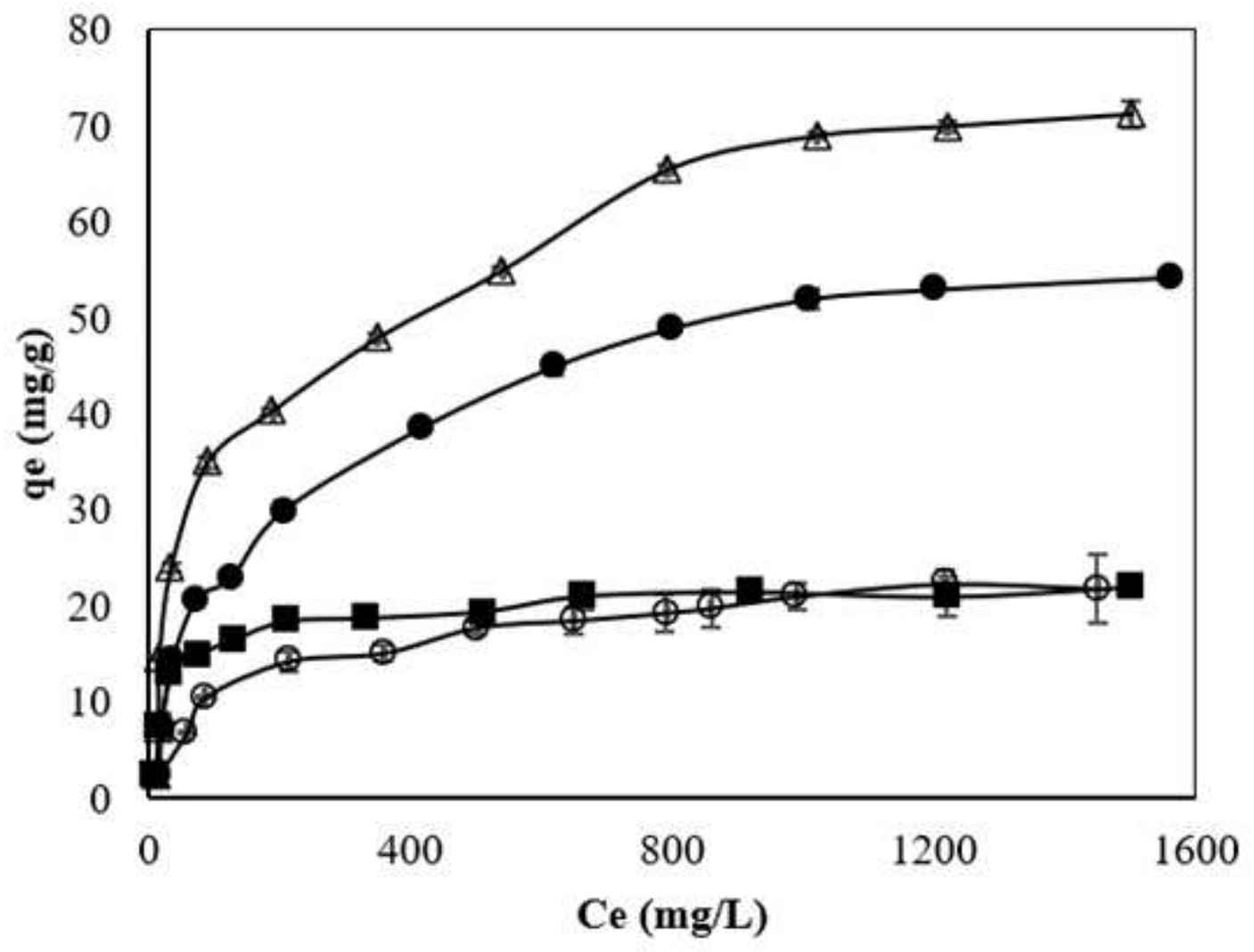

Figure 1

Adsorption isotherms of $\mathrm{Pb}(\mathrm{II})$ in materials with several OM content: $\nabla 0 \%, \nabla 1 \%, \nabla 5 \%, \Delta 10 \%$ at $298 \pm 1 \mathrm{~K}$, $\mathrm{pH} 7, \mathrm{l}=0.01 \mathrm{M}$ NaNO3. 


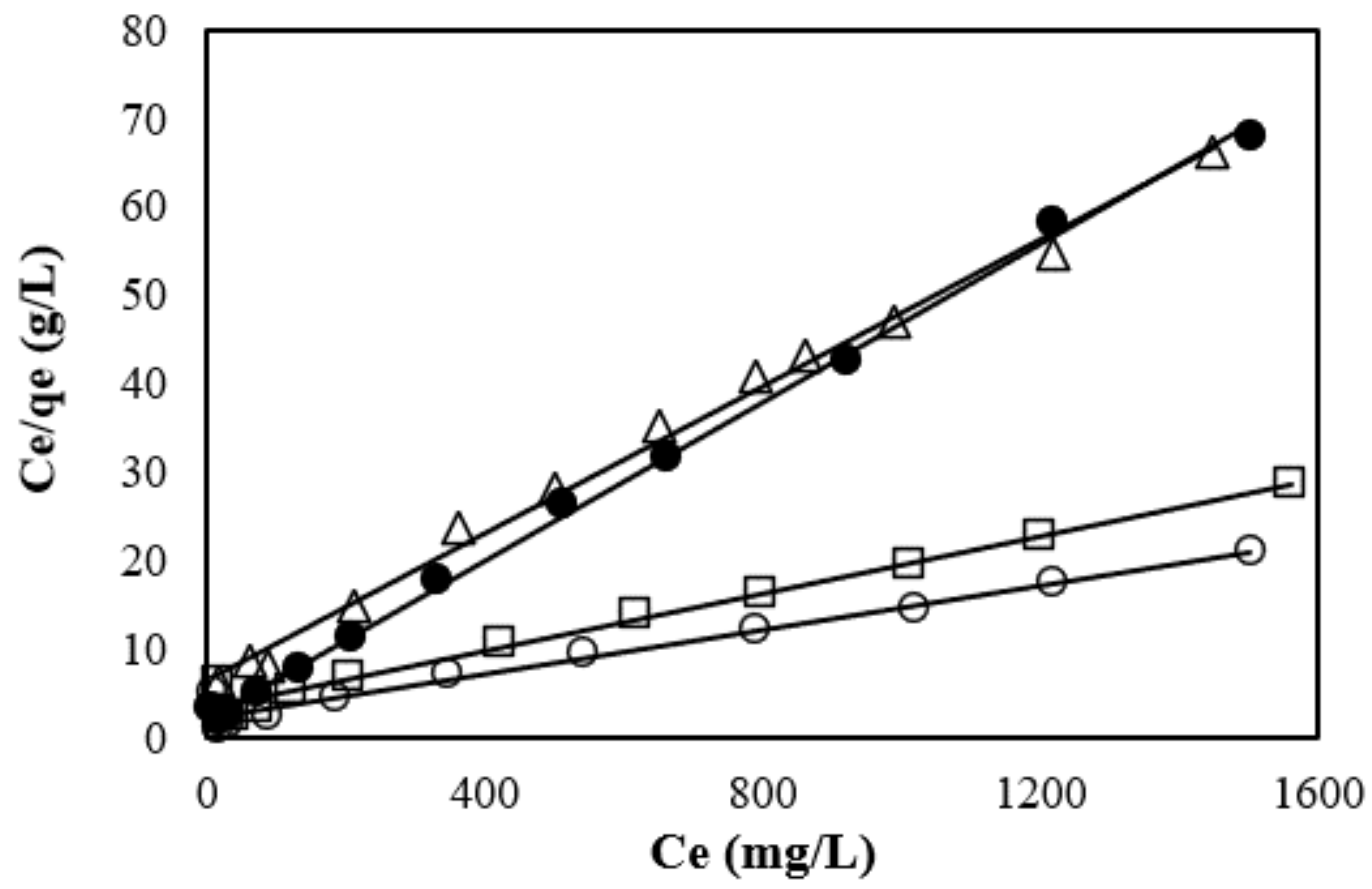

Figure 2

Linearization of Langmuir isotherm for lead adsorption on soils with $\Delta 0 \%, \nabla 1 \%, \nabla 5 \%, \nabla 10 \%$ at $298 \mathrm{~K}, \mathrm{pH}$ 7, I=0.01 M NaNO3

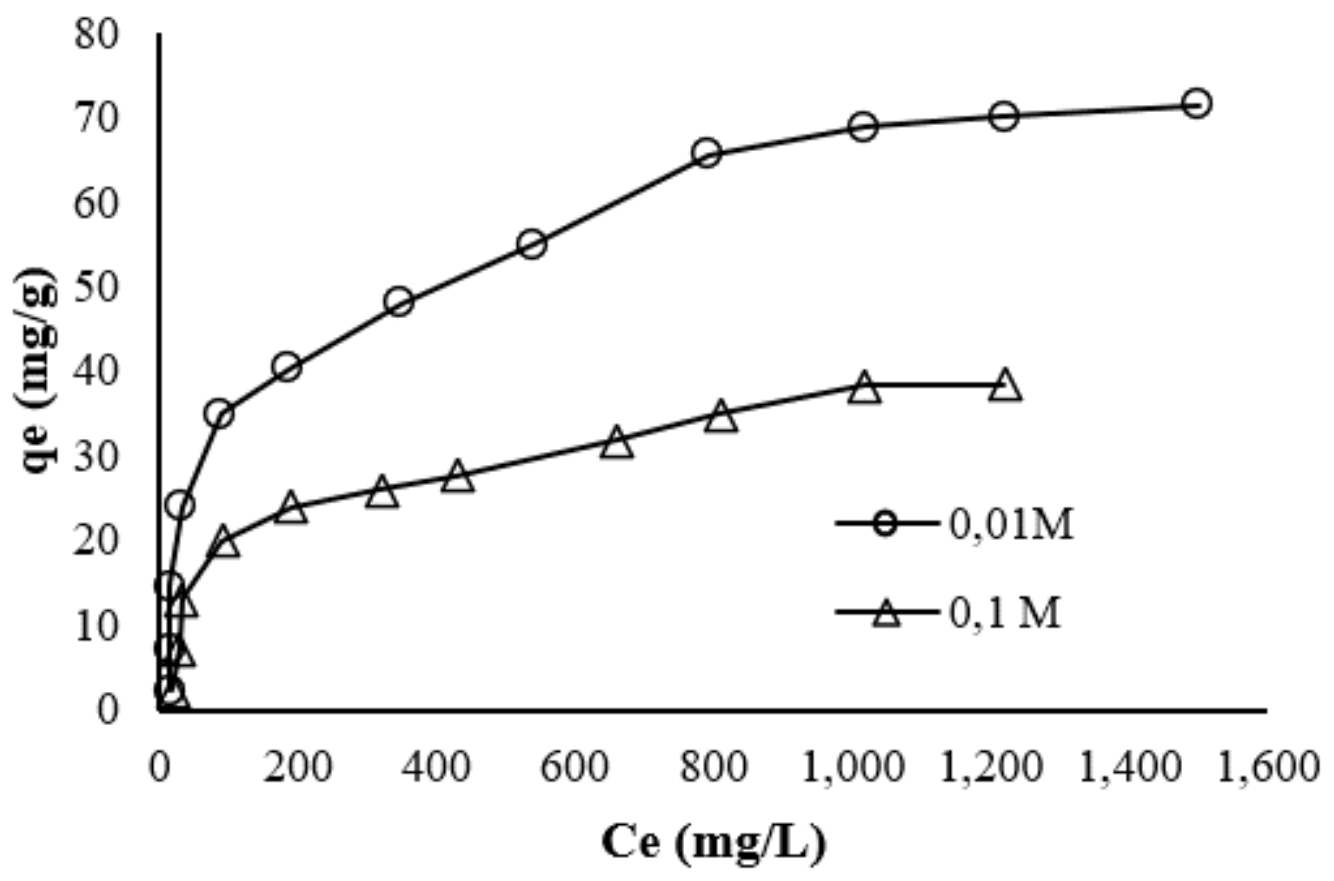

Figure 3 
Effect of ionic strength on the adsorption capacity of $\mathrm{Pb}$ (II) in 10-OM $\otimes 0.01 \mathrm{M}$ and $\otimes 0,1 \mathrm{M}$ of NaNO3 in $\mathrm{pH} 7$ at $298 \pm 1 \mathrm{~K}$

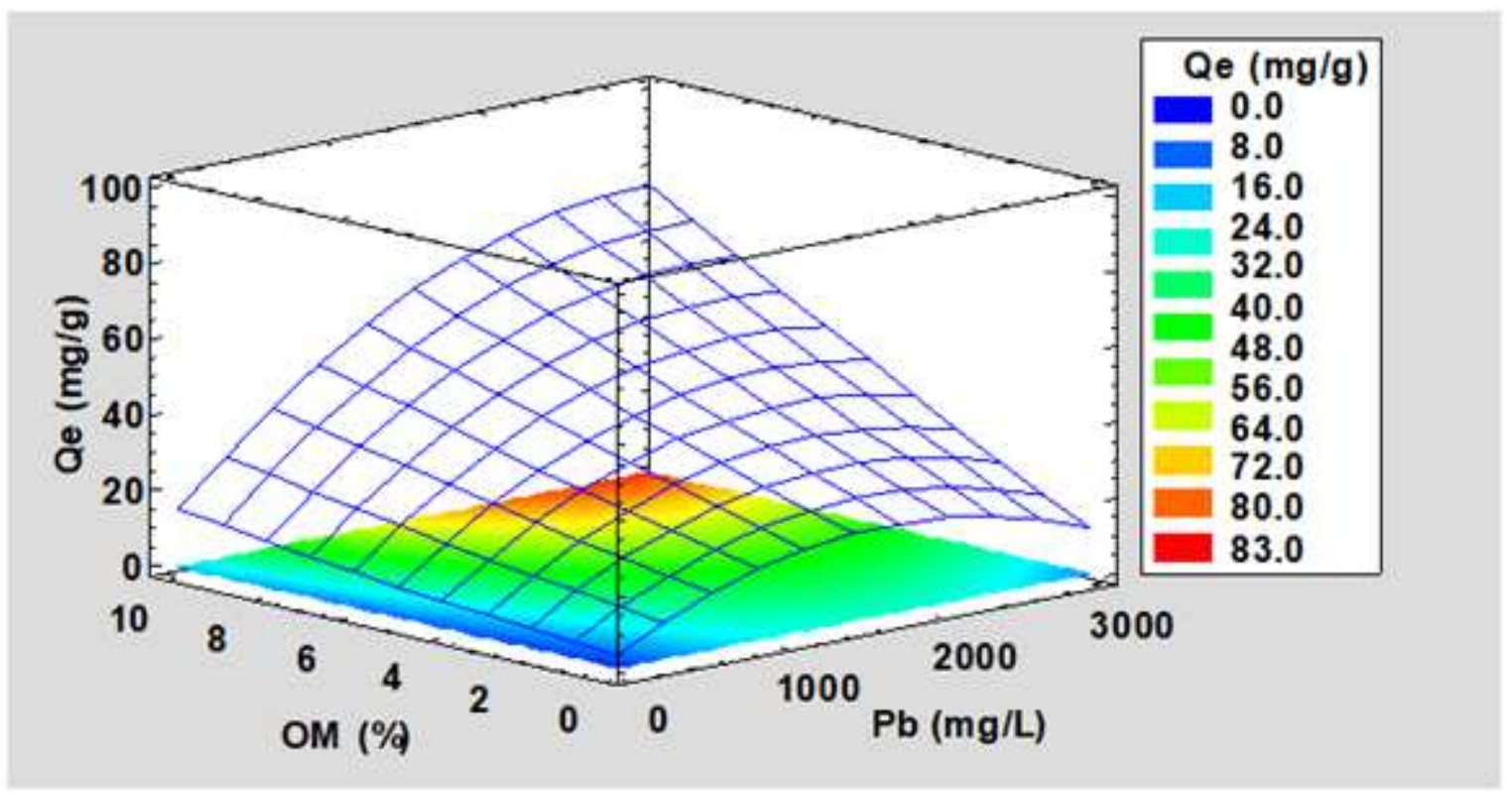

Figure 4

Response surface of the effect of organic matter and initial $\mathrm{Pb}$ (II) concentrations on the adsorption capacity at $\mathrm{pH} 7.0, \mathrm{l}=0.01 \mathrm{M} \mathrm{NaNO}$ and $298.15 \mathrm{~K}$.

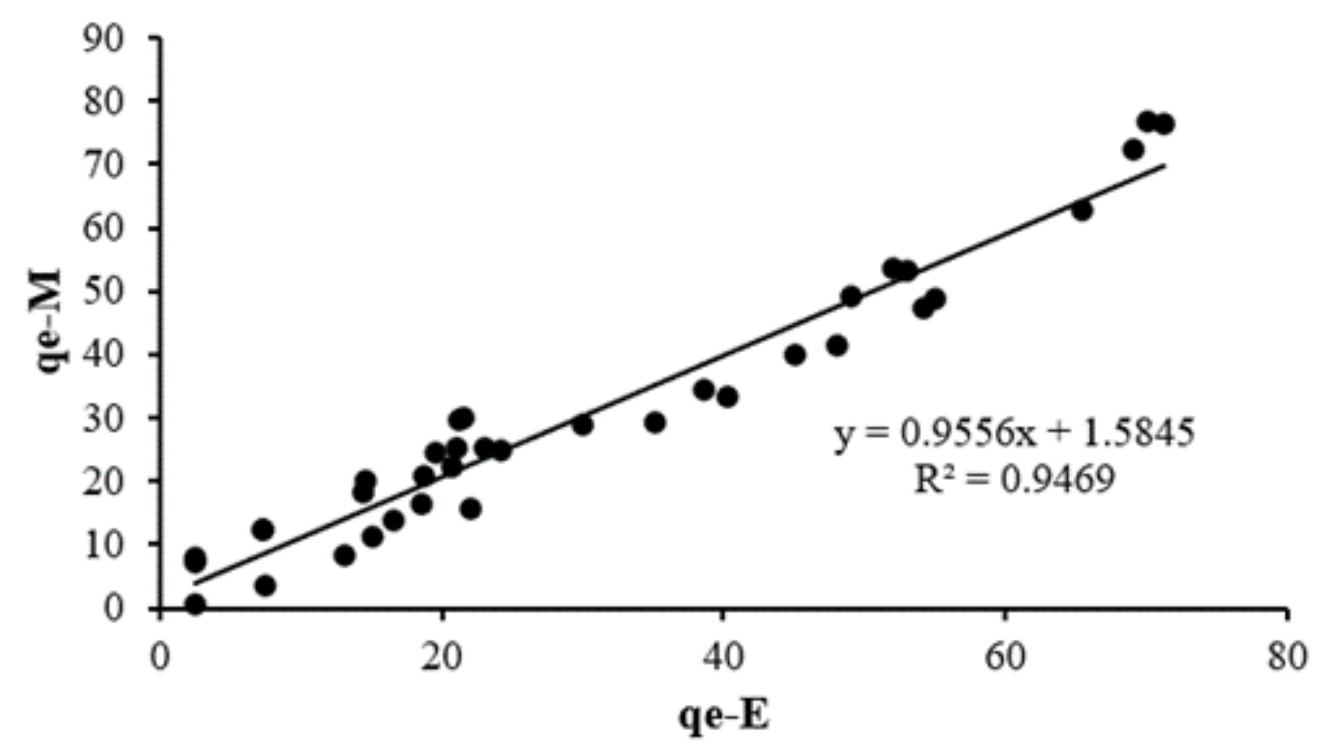

Figure 5

Comparison between adsorption capacity of experimental (qe-E) and modeled (qe-M) data 


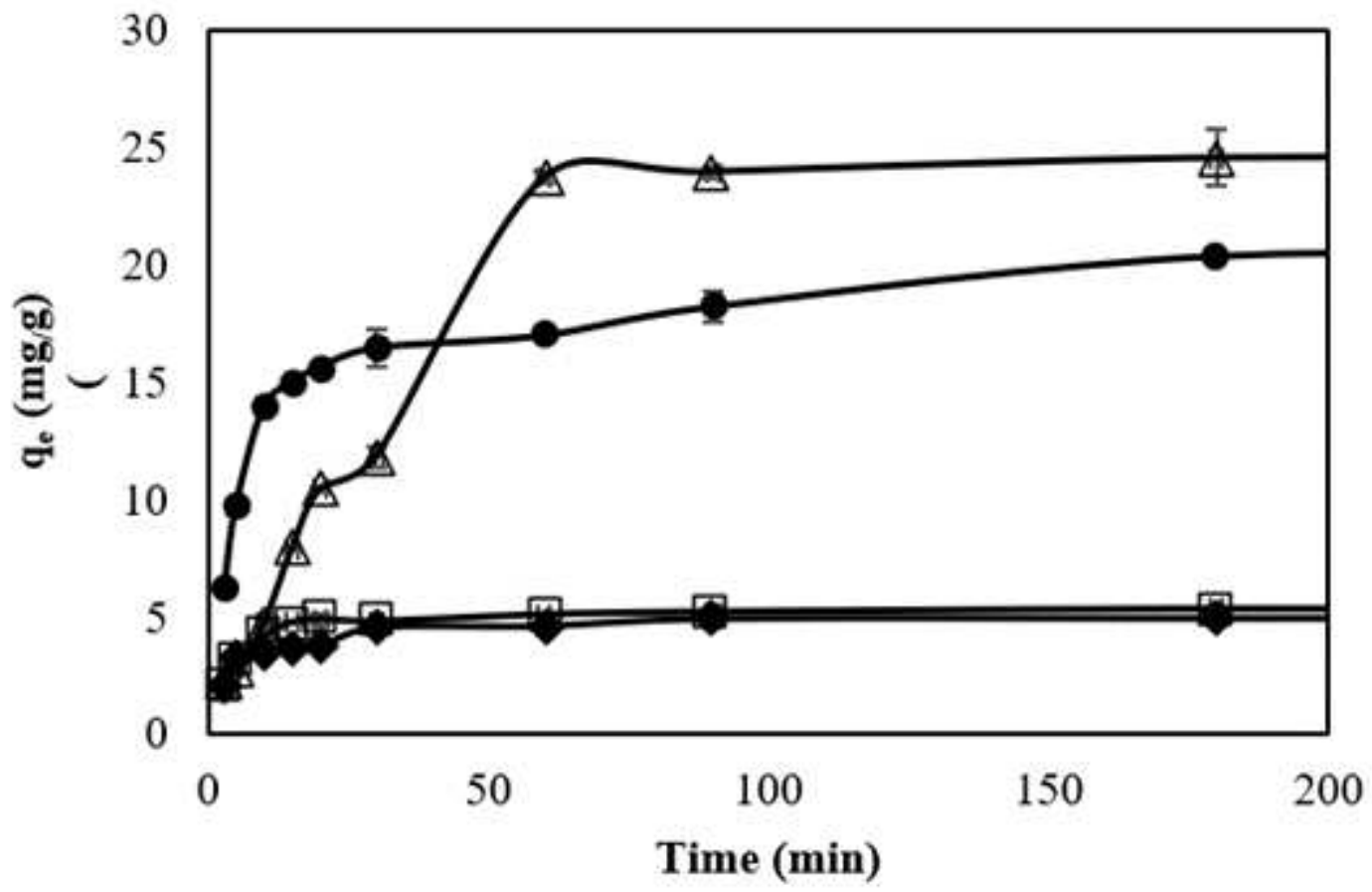

Figure 6

$\mathrm{Pb}$ (II) adsorption capacity for perturbed soils with several OM content $\otimes 0 \%, \nabla 1 \%, \otimes 5 \%, \Delta 10 \%$ at $298 \pm 1$ $\mathrm{K}, \mathrm{pH}, \mathrm{l}=0.01 \mathrm{M} \mathrm{NaNO3}, \mathrm{Cpb} 2+$ (initial) $=500 \mathrm{mg} / \mathrm{mL}$ 